\title{
Cinema education method, is it work for group guidance and counseling?
}

\author{
Henny Christine Mamahit \\ Universitas Katolik Atma Jaya Jakarta, Indonesia
}

\begin{tabular}{l} 
Article Info \\
\hline Article history: \\
Received Sep $11^{\text {th }}, 2020$ \\
Revised Oct $27^{\text {th }}, 2020$ \\
Accepted Nov $07^{\text {th }}, 2020$ \\
\hline Keyword: \\
Group guidance \\
Group counseling \\
Cinema education method \\
\end{tabular}

\begin{abstract}
Group guidance and counseling services are services provided to students to develop life skills both academically and non-academically. Group guidance and counseling services are intended to develop attitudes and behaviors that bring goodness to students. The cinema education method is a method that uses film media to provide group guidance and counseling services. The cinema education method can be a means to help students understand their living conditions, the needs they want to fulfill, and can provide a perception that sees that everything or problems has a way out. Learning experiences obtained from films can help students develop ideas or solutions to help themselves.
\end{abstract}

\section{Corresponding Author:}

(C) 2020 The Authors. Published by Redwhitepress

This is an open access article under the CC BY-NC-SA license (https://creativecommons.org/licenses/by-nc-sa/4.0/

Henny Christine Mamahit

Universitas Katolik Atma Jaya Jakarta

Email: henny.christine@atmajaya.ac.id

\section{Introduction}

Guidance and counseling services in schools are part of the educational process undertaken by students. Guidance and counseling services are services for the individual development of students who are not only oriented towards solving current problems, but also on developing skills and behavior that are oriented towards the future (Kamaluddin, 2011). Guidance and counseling services are an effort to help the development of all these aspects to be optimal, harmonious, and reasonable by the school counselor together with other educators. (Bhakti, 2015). In other words, the learning process in education which aims to optimize students is a guidance process. All potential of students must be developed in terms of intellectual, moral, social, cognitive, and emotional.

Guidance and counseling services are professional services that aim to help individuals achieve their developmental tasks which include personal, social, academic and career aspects (Kamaluddin, 2011; Bhakti, 2015; Kurniawan, 2015). Regarding the personal-social aspect, of the 11 things described, one of the goals of guidance and counseling is that students have the ability to make decisions effectively. This is reviewed again in the purpose of guidance and counseling, namely so that students have the ability and maturity to make decisions (Kamaluddin, 2011; Bhakti, 2015; Kurniawan, 2015).

In realizing professional guidance and counseling services in schools, counselors are expected to have the ability to skillfully master and apply services, both guidance and counseling services (Kamaluddin, 2011; Bhakti, 2015; Prasetiawan, 2017). Effective guidance and counseling services can develop life skills. One of the BK services that can be done is group guidance and counseling services. 
In realizing group guidance and counseling services, counselors are expected to have the ability to be skilled, master and apply effective and efficient group guidance and counseling methods. The Effectiveness of group guidance and counseling methods, especially when school counselors can help students improve understanding, attitudes and behavior. One of the methods / techniques of guidance that can be applied in training life skills to students is the cinema education method. The cinema education method is a method that can be used as a media for skills training (Mamahit, 2013).

The purpose of this article is to explore the method of cinema education and stages to apply it. This study will hopefully contribute positively both to the development of guidance and counselling services.

\section{Discussions}

This group guidance is an activity that is quite often carried out by school counselors. Group guidance is one of the guidance carried out by school counselors which has two functions (Brown, 2004; Erford, 2010; Kamaluddin, 2011; Bhakti, 2015; Kurniawan, 2015). The first function is the function of developing (developmental) attitudes, behaviors or new skills needed by students. The second function is the function of preventing unwanted attitudes or behaviors (Brown, 2004; Erford, 2010; Kurniawan, 2015). Group guidance can be a means for students to develop themselves or want to master a skill (Brown, 2004; Erford, 2010; Mamahit, 2013).

Group guidance is seen to be much more effective than personal guidance (Roshita, 2015). It is said to be more effective based on several reasons, including: it is more effective in terms of time for school counselors, sometimes school counselors find a lot of information about students' personal selves compared to personal guidance, group guidance is also an effective means for students who are embarrassed to do or undergo personal guidance. Students assume that they have friends (feel they are not alone) through the process of guidance and counseling (Mamahit, 2013). In addition, counselors can obtain accurate data relating to both individual students and the conditions of student groups. (Brown, 2004; Erford, 2010; Roshita, 2015).

Therapy using film (movie) was first used by the psychoanalytic approach accidentally. In connection with the dream analysis developed by Freud (in Packer, 2007), cinema shows the dream-like parts that appear when individuals sleep. Cinema is an innovation from dream analysis that can be interpreted scientifically (Packer, 2007). It is this coincidence that has finally connected psychology and cinema to this day.

The cinema education method or method of therapy using film media is a method developed from the bibliotherapy method (Mamahit, 2013). The cinema education method is an innovative method and development of cinematherapy (Packer, 2007; Mamahit, 2013). The cinema therapy method is a method that uses films as a learning medium for students to gain learning experiences. Film is a form of communication at the medium level. (Mamahit, 2013; Mojdeh, Zamani, Kooshki, \& Jafari, 2013). This is because films use moving images to evoke memories, show behavior, evoke emotions, and generate perceptions for the audience. Perception is associated with dynamic real life (Packer, 2007; Mamahit, 2013).

Several studies have shown that the cinema method is an effective method both in conducting learning, intervention, and guidance. Cinema or film produces a strong emotional impact to demonstrate the abstract concept of a theory (Champoux, 1999; Mamahit, 2013). Based on research data presented by Champoux (1999), educators since the 1970s have used film as a learning tool / method.

Wegner is credited with starting the use of cinema in 1977, which saw success in the learning process in various disciplines. Cowen (in Champoux, 1999; Mamahit, 2013) uses popular films to teach thinking systems to students. The results showed that students were able to analyze what was shown in the film and then relate it to real life problems or situations. Based on research conducted by Cowen (in Champoux, 1999; Mamahit 2013), it shows that films are significantly effective in teaching students how to think.

Through the cinema education method, there are several advantages that can be obtained by students as illustrated by Champoux (1999), namely that films are an economical substitute for field trips or other visits to obtain information; films can offer a powerful experience for students, especially those who do not like the concept of learning in "classrooms"; students can understand abstract concepts and theories that are not easily taught just by lecturing, but through films can be explained in real terms and in language that is easy to understand; and another advantage is that students can see, learn and gain experiences from other people, especially if the parts in the film are different from their local environment, but face the same situation or dilemma. (Champoux, 1999; Mamahit, 2013). 
Ward's research (1966) shows that the use of films in health education can help parents get ideas for dealing with children. Ward (1966) used film to show stressful conditions and how to deal with children with physical disabilities. This method shows parents can reflect what they see in films to their lives and try to apply it at home. Ward (1966) research shows the contribution of cinema to health education. Researchers used films to show stressful conditions and how to deal with physically disabled children. This method shows parents to reflect on what they see in the film on their lives and try to practice it at home.

Research conducted by Vroom \& Jago \& Yetton (in Champoux, 1999) proves that students can analyze each part (scenes) of the film in small groups using general knowledge to train how to solve problems, individual decision making, and group decisions. Vroom \& Jago \& Yetton's research also found that students were able to analyze every part of the film using a decision tree developed by Vroom-Yetton as a decision model to see which process and model was right for making the right decision.

Research conducted by Utami (2011) on junior high school students to practice problem-solving skills found that cinema education is beneficial for students in understanding and finding good solutions in dealing with problems. Through the film that was watched, students stated that they obtained new ideas that could help students solve their problems.

This statement can be seen in the results of research conducted by Muslihati (2011). Muslihati (2011) applies films in learning through real experiences in cross-cultural counseling courses for prospective counselors. Muslihati's research results indicate that prospective counselors get deep emotional experiences and impressions when watching the film, The Freedom Writer. Prospective counselors stated that they liked learning with films and were able to be more reflective so that they were able to make good self-commitments, especially in terms of respecting existing cultural differences.

Mamahit's (2013) research was conducted on high school students using the CBTS method, namely the Cinema education method based on true stories. The CBTS method is applied to group guidance services. The results showed that the use of films, especially films based on someone's true story, was able to increase understanding and practice personal decision skills (Mamahit, 2013).

Ningsih, \& Karyanti, (2017) conducted a study using educational cinema to train career decisionmaking skills. This research was conducted on a group of vocational students. The results showed that the career decision-making skills of students who were initially in the low category experienced a moderate increase. This condition occurs after being given the cinema education method (Ningsih, \& Karyanti, 2017).

Based on the exposure of several studies, the cinema education method is seen as a method or intervention, it can be concluded that the cinema education method is an innovative method or intervention using film as a source to obtain a concrete picture of an abstract concept, causing emotional reactions. In addition, film is a medium that provides understanding for the development of new ideas generated through understanding so that it can be applied in the real life of an individual. Films can provide learning stimulation. Students can see experiences by seeing directly or real how a person can respond to issues that arise in his life.

Films have a function in education or in the learning process. elaborates that several film functions include: (a) film as a case. Analysis of a case can help develop students' analytical skills. Some films bring students to a predictive approach to cases so that they can achieve a process of discussion and reinforcement of concepts and theories; (b) film as experiential exercise. Some films give inclusion to students and provide experiences to students; (c) film as a metaphor. Films can provide or create metaphor images, have visual power about abstract concepts or theories. The film description is a metaphor of the main idea that you want to show or want to develop; (d) the film as satire (satire). Films can provide an effective satire to "burn" the concept that is in a person's mind. The satire in the film focuses on people's and social mistakes. Satire can provide a memorable picture of something that is being emphasized to be developed in students; (e) film as a symbol. The scene in the film is a symbol for communicating theories and concepts; (f) film as a meaning. The audio and visual images of a film can convey a deep message and impression and are sometimes much better than just pronouncing words; and (g) films as time. Films shoot early periods that can show aspects of behavior. (Champoux, 1999; Stinchfield, 2006; Mamahit, 2013; Reddy, G. V., Heisler, M. G., Ehrhardt, D. W., \& Meyerowitz, E. M., 2004; Salt, B.,2020; Higson, A.,2020;Gallese, V., \& Guerra, M. (2019).

The method of cinema education in its application in group guidance and counseling services has advantages and disadvantages. The weaknesses in using the cinema education method include the long time it takes to prepare a film that is suitable for the theme to be presented (Stinchfield, 2006). Movies must be chosen with great care. The film must be able to describe psychological constructs that students can clearly accept and think about. The training implementer (facilitator, teacher, counselor) must first study the film before being watched by students. The trainer must understand the characters in the film and all parts of the film. It is 
certain that the contents of the film can be analyzed so that they can be studied appropriately. The training implementer must formulate clear instructions (Mamahit, 2013).

The different emotional reactions of each individual are another weakness (Zimmer 2017). It is said to be a weakness because not all individuals or students who will take part in the training have the same emotional reactions or as the implementer hopes. There are some students who reject or annoy or even "sneer" about some parts of the film; or there are some students who are sensitive to the scenes shown in the film; or indeed there are students who react as expected.

The screening time of the film took a long time compared to the usual class hours. This is another drawback. Films take up time and time away from other classroom activities. Cutting scenes help to overcome time, but on the other hand can reduce the meaning or message to be conveyed (Champoux, 1999).

The cinema education method has advantages that can make it an effective method in practicing a skill. Movies in class or the learning process can help the instructor or teacher, or counselor get out of the boring routine of teaching with classical methods. Films can bring out the creativity of students in conveying ideas or thoughts or explanations that may not have been previously suspected by the instructor or teacher or counselor. (Stinchfield, 2006; Shepard and Brew in Wu, 2008; Mamahit 2013).

A film or a scene from a scene if it is played several times will provide a deep understanding of an interaction between humans. Films are able to bring about different reactions and make the process of discussion and reflection come alive in the classroom (Shepard and Brew in Wu, 2008; Mamahit, 2013; Zimmer, 2017). Films can also be role models and can guide students in implementing roleplay to translate abstract theories or concepts (Champoux, 1999; and Shepard, 2005; Mamahit, 2013; Zimmer. 2017).

The use of cinema education methods in group guidance and counseling services requires stages of activity. The stages of this cinema education method are adapted from research conducted by Mamahit (2013). The stages of activities of the cinema education method are as follows.

The first stage is the preparation stage. At this stage the counselor needs to do several things, namely: (a) finding films that are in accordance with the theme of the services to be provided; (b) watching movies to be shown for the service. The counselor needs to observe carefully the storyline of the film, especially the parts that show a connection with the theme; (c) prepare a clear reflection sheet containing items or components that directly address the theme of group guidance and counseling services; (d) The counselor acts as a student by trying to fill out the reflection sheet. This is done so that it becomes an evaluation for improvement on the reflection questions; (e) Counselors prepare guidelines with clear and concrete instructions, so that students can do or follow these guidelines easily.

The second stage is the implementation stage. At the implementation stage there are several sub-stages that students will go through, namely: a) Introduction. In the introductory stage, students get a brief description, characteristics, and objectives of the theme to be carried out. In addition, students get brief information related to the storyline of the film to be watched; b) Watch (Watch). At this stage students watch the entire film clearly; c) Discussion (Discussion). At the discussion stage, after students watched the film until the end, students were invited to discuss the characters and what happened in the film. This stage is carried out so that students can get a picture of the process contained in the film; d) Reflection (Reflection). In the reflection stage, the writer adapts the method developed by Remer (2007). The relevant and applicable reflection stages are ground, understand, revised, and use (G-U-R-U).

At the ground stage, students answer the questions contained in the reflection guide. The questions were asked to reveal the basic impression and understanding obtained by students. The second stage is understanding. Learners are invited to describe the understanding obtained in a broader context through comparisons to similar experiences that occur in personal life. After students describe their understanding, students enter the third stage, namely revised.

In the revised stage, students design steps based on their learning experiences that inspire themselves. This section is a personal reflection experienced by students. At this stage students adapt the strategies or methods or things that have been learned through film reflection into the real world. Students are expected to find new concepts so that they can be applied in the same situation. The next stage and is the final stage of the reflective process is the use stage. Researchers merge this use stage into the next stage of the cinema education stage, namely the application stage.

The third stage is the application stage. The application stage and the use stage in the reflexive process have the same goal, namely, to know how to design or what actions students take as a form of implementing the results of student reflections. Students get the opportunity to apply the concepts obtained to the real 
problems faced. At this stage students will get an Action Task sheet. Action Task contains any actions or actions that will be carried out by students as a form of real reflective that is concrete, clear, easy to measure, and can be done by students themselves. This application is triggered or expressed in the self-commitment of students. At this stage, the counselor also observes the course of the intervention.

The last stage or the fourth stage is the evaluation stage. In the evaluation stage, the counselor assesses the course of group guidance and counseling service interventions. The counselor evaluates through observing the processes experienced by students. The counselor can carry out his own evaluation regarding the process of implementing the intervention or the counselor is assisted by other parties, including the school counselor. The counselor can ask students to provide feedback to get an objective assessment.

\section{Conclusions}

Based on the explanation above, it relates to cinema education as a method or intervention in group guidance and counseling services. The cinema education method is an innovative therapeutic or intervention method using film or cinema as a learning resource. In group guidance and counseling services, the cinema education method can provide students with an overview of concrete or easy-to-understand concepts, generate emotional reactions, and as a means of generating new ideas generated through understanding.

This understanding can be applied in the real life of students or it can be a solution to the problems it faces. The cinema education method can be an alternative help to provide an idea that students can understand a life condition by looking at the experiences of others. With students seeing that there are other people who experience or face the same thing as what they have experienced, then to achieve a goal or in order to meet a need or want to solve a problem or respond to an issue that is present in their life, it will be much easier to realize.

\section{References}

Bhakti, C. P. (2015). Bimbingan dan Konseling Komprehensif: Dari Paradigma Menuju Aksi. Jurnal Fokus Konseling, 1(2), 93-106.

Brown, N. M. (2004). Psychoeducational Groups: Process and Practice (2nd Ed.). London: BrunnerRoutledge.

Champoux, J. E. (1999). Film as a teaching resource. Journal of management inquiry, 8(2), 206-217.

Dalzell-Ward, A. J. (1966). The Contribution of Cinema and Television to Health Education. Health Education Journal, 25(3), 120-129.

Erford, B. T. (2010). Group Work in the Schools. Boston: Pearson Education Inc.

Farré, M., Bosch, F., Roset, P. N., \& Baños, J. E. (2004). Putting clinical pharmacology in context: the use of popular movies. The Journal of Clinical Pharmacology, 44(1), 30-36.

Gallese, V., \& Guerra, M. (2019). The Empathic Screen: Cinema and Neuroscience. Oxford University Press.

Higson, A. (2020). 'Medievalism', the period film and the British past in contemporary cinema. In Medieval film. Manchester University Press.

Kamaluddin, H. (2011). Bimbingan dan konseling sekolah. Jurnal Pendidikan dan Kebudayaan, 17(4), 447454.

Kurniawan, L. (2015). Pengembangan Program Layanan Bimbingan dan Konseling Komprehensif di SMA. Jurnal Psikologi Pendidikan \& Konseling, 1(1), 1-8.

Mamahit, H. C. (2013). Keefektifan metode cinemaeducation based on true story (CBTS) pada pelatihan keterampilan pengambilan keputusan pribadi siswa SMA (Doctoral dissertation, Universitas Negeri Malang).

Mojdeh, S., Zamani, M., Kooshki, A. M., \& Jafari, N. (2013). Effect of watching a movie on family members' anxiety level during their relatives' surgery. Iranian journal of nursing and midwifery research, 18(4), 329.

Muslihati, M. (2012). Penerapan Pembelajaran Melalui Pengalaman pada Perkuliahan Konseling Multibudaya.(Disertasi). DISERTASI dan TESIS Program Pascasarjana UM.

Ningsih, K., \& Karyanti, K. (2017). Keefektifan Cinema Education Pada Pelatihan Keterampilan Pengambilan Keputusan Karir Pada Peserta. Suluh: Jurnal Bimbingan dan Konseling, 3(1), 8-15.

Packer, S. (2007). Movies and the modern psyche. Westport: Praeger Publisher.

Powell, M. L., \& Newgent, R. A. (2010). Improving the empirical credibility of cinematherapy: A singlesubject interrupted time-series design. Counseling Outcome Research and Evaluation, 1(2), 40-49.

Prasetiawan, H. (2017). Optimalisasi Multimedia Dalam Layanan Bimbingan dan Konseling. In Prosiding Seminar Bimbingan dan Konseling (Vol. 1, No. 1, pp. 199-204). 
Reddy, G. V., Heisler, M. G., Ehrhardt, D. W., \& Meyerowitz, E. M. (2004). Real-time lineage analysis reveals oriented cell divisions associated with morphogenesis at the shoot apex of Arabidopsis thaliana. Development, 131(17), 4225-4237.

Remer, B. (2007). Reflective Practice: Learning from Real - World Experience. Dalam Silberman, M. (ed.). The handbook of Experiential Learning. San Fransisco: John Wiley \& Sons. Inc.

Roshita, I. (2015). Upaya meningkatkan perilaku sopan santun melalui layanan bimbingan kelompok dengan teknik sosiodrama. Jurnal Penelitian Tindakan Bimbingan \& Konseling, 1(2).

Salt, B. (2020). The style of Ingmar Bergman's films. New Review of Film and Television Studies, 1-24.

Stinchfield, T. A. (2006). Using popular films to teach systems thinking. The Family Journal, 14(2), 123-128.

Utami, N.W. (2011). Pengembangan Panduan Pelatihan Keterampilan Pemecahan Masalah (Problem Solving Skill) dengan Cinemaeducation untuk siswa SMP. Thesis. Malang: Program Pascasarjana Universitas Negeri Malang.

Wu, A. Z. (2008). Applying cinema therapy with adolescents and a cinema therapy workshop. East Bay: California State University.

Zimmer, T. (2017). Four Ways Movies Can Relieve Stress. Mental Health Matters. Retrieved from https://mental-health-matters.com/four-ways-movies-can-relieve-stress 